\title{
IZVJEŠTAJ O ARHEOLOŠKOM NADZORU NA PAVLINSKOM TRGU U SENJU (STUDENI 2019. - LIPANJ 2020.)
}

Blaženka Ljubović

Gradski muzej Senj

Milana Ogrizovića 5

HR 53270 Senj

gradski.muzej.senj@gs.t-com.hr
UDK: 902.2(497.5Senj)

Stručni članak

Ur.: 2021-06-29

Arheološki nadzor nad građevinskim radovima uređenja Pavlinskog trga u Senju proveo je Gradski muzej Senj. Stručna voditeljica predmetnoga nadzora bila je Blaženka Ljubović, mag. educ. hist. i mag. archeol. uz konzervatorski nadzor Vinka Madirace, dipl. arheolog iz Konzervatorskog odjela u Gospiću. Navedeni građevinski radovi provedeni su u razdoblju od studenog 2019. do kraja lipnja 2020. godine.

U prošlosti, prema povijesnim izvorima, Pavlinski trg u Senju je lokacija na kojoj se nalazio dominikanski, a potom i pavlinski samostan s crkvom sv. Nikole, koji je zbog trošnosti porušen 1874. godine s dijelom gradskog bedema u predjelu starih morskih vrata. Predmet ovog rada arheološki je nadzor na zaštiti lokaliteta Pavlinski trg (prostora nekadašnje pavlinske crkve sv. Nikole i samostana u Senju) tijekom građevinskih radova na uređenju Trga. Nadzor se vršio u svrhu prikupljanja svih bitnih informacija o kulturnim slojevima i arheološkim nalazima, posebice zato što je tijekom ranijih arheoloških istraživanja evidentiran arheološki materijal (grobni nalazi) iz pojedinih povijesnih razdoblja crkveno-samostanskog kompleksa, kao i nepokretna arhitektonska struktura, arheološki zanimljiva, na određenim dubinama od razine pločnika Pavlinskog trga. Cilj arheološkog nadzora bilo je utvrđivanje gabarita crkve i samostana te zaštita eventualnih grobova unutar crkve od moguće devastacije.

Ključne riječi: Senj, Pavlinski trg, crkva i samostan sv. Nikole, arheološki nadzor, srednji vijek, novi vijek, grobovi, zidovi, ljudske kosti, keramika, novac

\section{Povijesni podaci o crkvi sv. Nikole sa samostanom u Senju}

Najstariji dokument u kojem se spominje crkva sv. Nikole u Senju potječe iz godine 1378. kada je darovana dominikancima (iz konteksta darovnice može se zaključiti da je riječ o manjoj crkvi), koji ostaju u Senju do 1634. godine, 


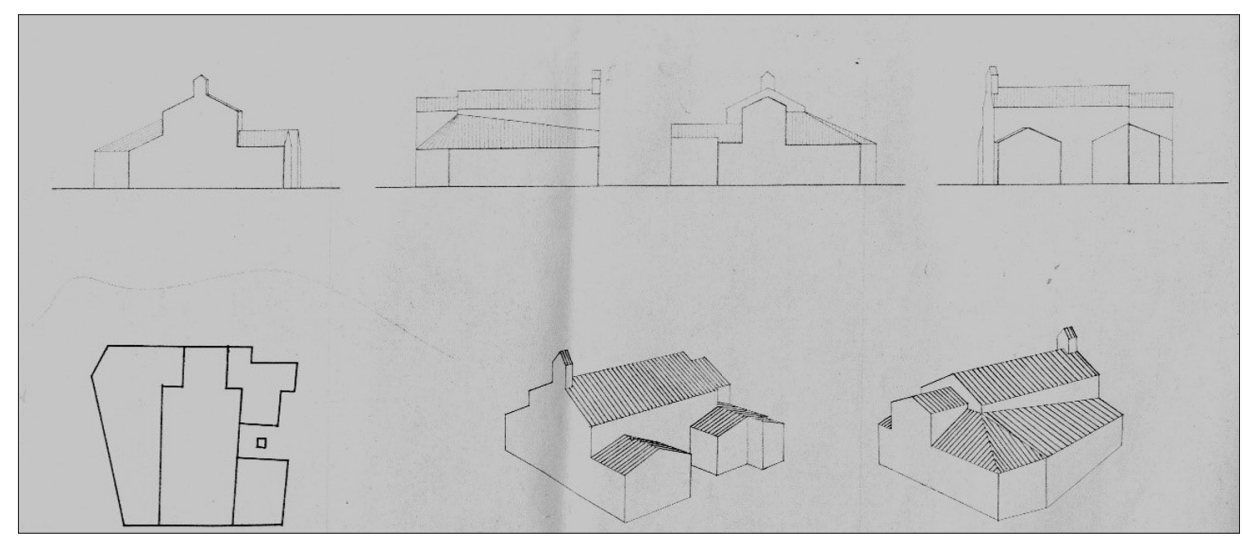

S1. 1. Tlocrtna grafička rekonstrukcija crkve sv. Nikole sa samostanom prema planu iz 1763. (izvor: M. VILIČIĆ, 1991, 296-298)

nakon čega samostan i crkvu preuzimaju pavlini. ${ }^{1}$ Prema skromnim podacima u literaturi značajno je napomenuti da se crkveno-samostanski kompleks na Pavlinskom trgu u prošlosti koristio i kao groblje za pokapanje senjskih građana i odličnika, što dokazuju objavljeni natpisi u literaturi. ${ }^{2}$ Pavlini su značajni za razvoj senjskog školstva. Godine 1725. osnivaju senjsku gimnaziju. ${ }^{3}$ Godine 1786. ukinut je pavlinski red, a samostan i crkva su sekularizirani. ${ }^{4}$

Podatke o izgledu crkve i samostana daju nam vedute i planovi grada Senja koje je u svojim radovima predstavila Melita Viličićs ${ }^{5}$, na temelju kojih zaključuje da je izvorno bila manja crkva s preslicom obuhvaćena zgradom samostana, a sredinom 17. stoljeća, kad je od dominikanaca preuzimaju pavlini, obnovljena je i povećana te dobiva i toranj. Tako je crkva sa zvonikom na preslicu prikazana na Stierovoj veduti iz 1660. i Valvasorovoj iz 1689. godine. Prikaz iz 1749. je s tornjem iznad kojeg piše Pauliner te takva ostaje do 1874., kada je zbog trošnosti porušena. Isto je prikazuje i fotografija Ivana Standla s kraja 19. stoljeća. Prvi tlocrtni prikaz datira iz 1763. godine, gdje je prikazana kao trobrodna građevina sa samostanom (S1. 5). Plan iz 1779. godine, kao i kasniji, prikazuju kompleks

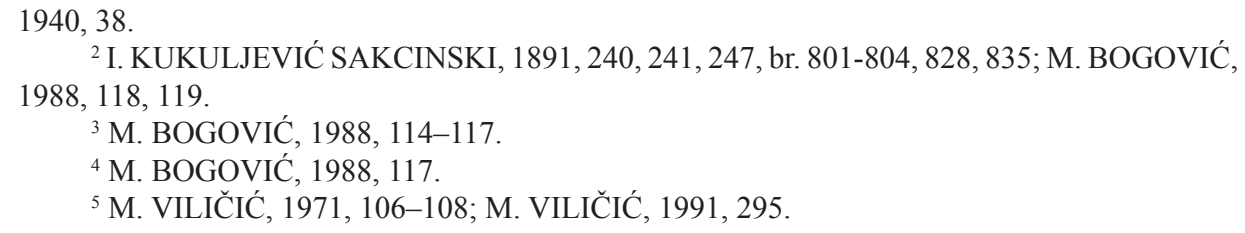

${ }^{2}$ I. KUKULJEVIĆ SAKCINSKI, 1891, 240, 241, 247, br. 801-804, 828, 835; M. BOGOVIĆ, $1988,118,119$.

${ }^{3}$ M. BOGOVIĆ, 1988, 114-117.

${ }^{4}$ M. BOGOVIĆ, $1988,117$.

${ }^{5}$ M. VILIČIĆ, 1971, 106-108; M. VILIČIĆ, 1991, 295.

${ }^{1}$ M. BOGOVIĆ, 1988, 117; M. MAGDIĆ, 1877, 31; P. TIJAN, 1931, 40, 41; HKS, JAZU, 


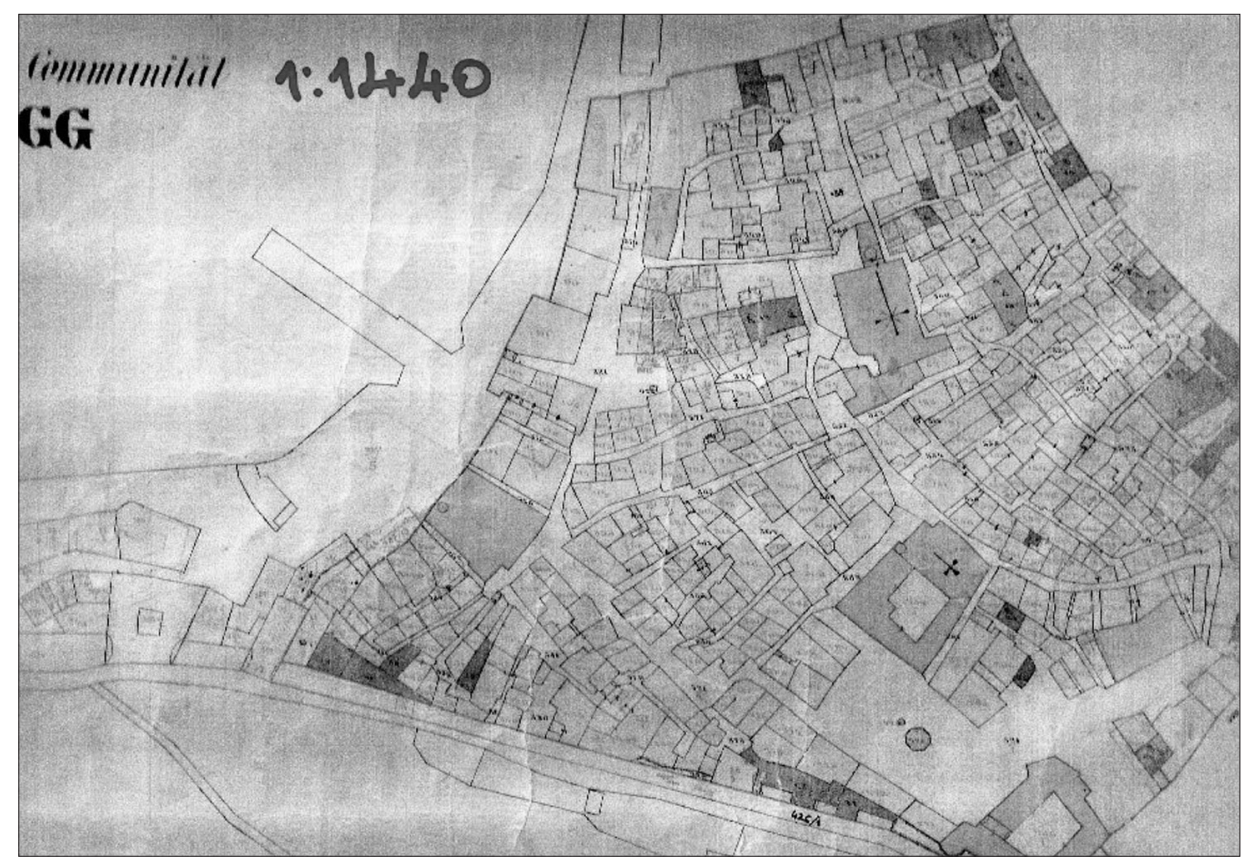

Sl. 2. Katastarski plan Senja iz 1870-ih godina s pozicijom Pavlinskog trga (izvor: Odjel za katastar nekretnina Senj)

crkve i samostana tlocrtno na mjestu gdje se bujica-potok slijevala u more. Pavlinskom crkvom i samostanom (smještajem, izgledom i preuređenjem) bavio se i Zorislav Horvat ${ }^{6}$. Također podatke o izgledu crkve i samostana, namjeni i važnosti tijekom povijesti donose i pojašnjavaju u svojemu radu Vedrana Glavaš i Miroslav Glavičić ${ }^{7}$.

Predmetnim arheološkim nadzorom pružila se prilika uvidjeti njezin izvorni izgled, dakle prije vremena kada je od dominikanaca preuzimaju pavlini koji je očito pregrađuju, dograđuju i dodaju joj toranj. Izvorni izgled crkve i samostana (onaj do 17. stoljeća) dosad prema dostupnim dokumentima (pisanim i grafičkim) nije bilo moguće sa sigurnošću utvrditi i grafički rekonstruirati. Međutim, ovim istraživanjima pružila se prilika utvrditi tlocrtno vidljive konture crkve i samostana prema skicama M. Viličić (S1. 1).

${ }^{6}$ Z. HORVAT, 1999, 163-167.

${ }^{7}$ V. GLAVAŠ - M. GLAVIČIĆ, 2012, 38-40. 


\section{Crkva sv. Nikole sa samostanom u Senju}

Bivši samostan i crkva sv. Nikole bili su smješteni gotovo uz same zidine uz more (danas Pavlinski trg). Pločnici su oblikovali ulice uz samostan s crkvom i time jasno naznačili tlocrtne konture ovoga sakralnog građevinskog kompleksa. Pretpostavka je da se konture crkve nisu bitno mijenjale u odnosu na plan iz 1763. godine na kojem je prikazana kao trobrodna građevina s kompleksom samostana, koji je obuhvaća (Sl. 5), što su ovi građevinsko-komunalni radovi trebali pokazati.

\section{Pavlinski trg u Senju - arheološki nadzor nad građevinskim radovima}

Arheološki nadzor započeo je u studenom 2019. godine i trajao do kraja lipnja 2020. godine. Na prostoru cijelog Trga za potrebe postavljanja podzemne komunalne infrastrukture, koja se odnosi na komunalne i telefonske te elektroinstalacije, bilo je potrebno ukloniti pločnik i recentni nasip ispod pločnika do dubine od oko $0,50 \mathrm{~m}$. To je učinjeno uz pomoć građevinske mehanizacije. Međutim, na dijelu gdje je bilo potrebno dodatno arheološko istraživanje, isto je obavljeno ručnim iskopom.

Povremeno je nadzoru stvarao problem i sam položaj lokaliteta s obzirom na to da se nalazi u neposrednoj blizini mora. Zbog navedenih okolnosti, zbog plime, dijelovi otkopanog terena i zidova često su se nalazili pod vodom. Tijekom nadzora posebno se vodilo računa o tome da je crkveno-samostanski kompleks korišten kao groblje za pokapanje pokojnika. ${ }^{8}$ Tijekom istraživanja na dijelovima lokaliteta u sklopu recentnog nasipa pronađeni su ostaci dislociranih ljudskih kostiju, što je posljedica ranijih građevinsko-komunalnih radova na Trgu. Također su pronađeni i razni ulomci keramike, ulomak stupića, antički novčić i kovanice jugoslavenskih dinara. (T. I-III) Nažalost, osim kostiju nije bilo drugih grobnih nalaza, zasigurno iz razloga što se grobovi nalaze u dubljim slojevima koji nisu bili zahvaćeni građevinskim radovima - ispod nivelete pločnika, na dubini do $0,50 \mathrm{~m}$. Pronađeni arheološki materijal dijelom pripada antičkom razdoblju (ručke i dna amfora i sl.). Također je pronađen novčić tipa Antoninijan iz vremena Klaudija II. Gotskog (268. - 270.); avers: glava s radijalnom krunom, desno; revers: CONSECRATIO, pravokutni monolitni žrtvenik (T. II).

Tijekom radova otkopani zidovi (tj. temelji crkveno-samostanskog kompleksa) definirani su na zadanoj dubini od oko $0,50 \mathrm{~m}$ te geodetski snimljeni. Gradnja zidova je solidna, izgrađeni su u vodoravnom slogu od grubo priklesanih

${ }^{8}$ A. GLAVIČIĆ, 1992, 89, 90. 
nepravilnih kamenih blokova različitih dimenzija vezanih vapnenom žbukom. Utvrđeno je da su temeljni vanjski zidovi debljine između 1,20 (zapadno pročelje) i 1,80 m (vanjski jugozapadni zid).

Pregledom je utvrđeno da su dijelovi otkopanih zidova - temelja crkve i samostana ranijim građevinskim zahvatima na trgu devastirani, zidni slog je ispremještan te na pojedinim mjestima lokaliteta gubi liniju budući da je dio pločnika ulice nalegao na zidove temelja crkve. Utvrđene su velike količine recentne građevinske šute i smeća pomiješanog $\mathrm{s}$ krovnom opekom, recentnom keramikom i staklom te komadima kamena (ostaci rušenja), kojim je uglavnom bio prekriven dio platoa nekadašnje crkve i samostana.

$\mathrm{Na}$ temelju viđenog zaključeno je da je lokalitet crkveno-samostanskog kompleksa devastiran ranijim građevinsko-komunalnim radovima na Pavlinskom trgu te uređenjem ulica uz graničnu (rubnu) liniju Trga, što je utvrđeno prilikom probnoga sondažnog arheološkog istraživanja na Trgu 2012. godine. ${ }^{9}$

\section{Analiza arhitektonskih ostataka}

Temeljem izrade arheološke nacrtne dokumentacije ostataka pavlinskog samostana donesene su određene pretpostavke o namjeni pojedinih zatečenih građevinskih konstrukcija, tj. dijelova strukture pavlinskog samostana u trenutku rušenja 1874. godine. Osim temelja originalnih dijelova samostana, utvrđeni su i temelji kasnijih gradnji fontane i baze spomenika te ostaci i linija obrambenog bedema prema moru.

Odulicanasjeveroistokuijugoistokusamostanjebioodvojenperimetralnim zidovima debljine između 1,20 (jugoistok) i 1,50 m (sjeveroistok), dok je od morske linije bio odvojen bedemom debljine oko 2,15 m na sjeverozapadu. Rušenje bedema prema moru uslijedilo je u drugoj polovici 18. st. u vezi s uređenjem obale za lučke potrebe. Linija bedema prema jugozapadu presječena je zidanom konstrukcijom nepoznate namjene, što bi moglo sugerirati skretanje bedema oštrije prema moru ili postojanje konstrukcije ojačanja bedema ili kule.

Uz južnu stranu sjevernog perimetralnog zida utvrđeno je pružanje paralelnog zida debljine oko $1,15 \mathrm{~m}$. Isti zid na sjevernom licu ima vidljivu konstrukciju u formi polupilona kao i perimetralni nasuprotni zid na unutarnjem licu. Između navedenih ojačanja zidova nalazi se samostalni temelj pilona ili stupa. Cjelokupni izgled konstrukcije sugerira da se uz unutarnje lice perimetralnog zida samostana na sjeveroistoku protezao natkriveni trijem.

${ }^{9}$ V. GLAVAŠ - M. GLAVIČIĆ, 2012, 43-44. 


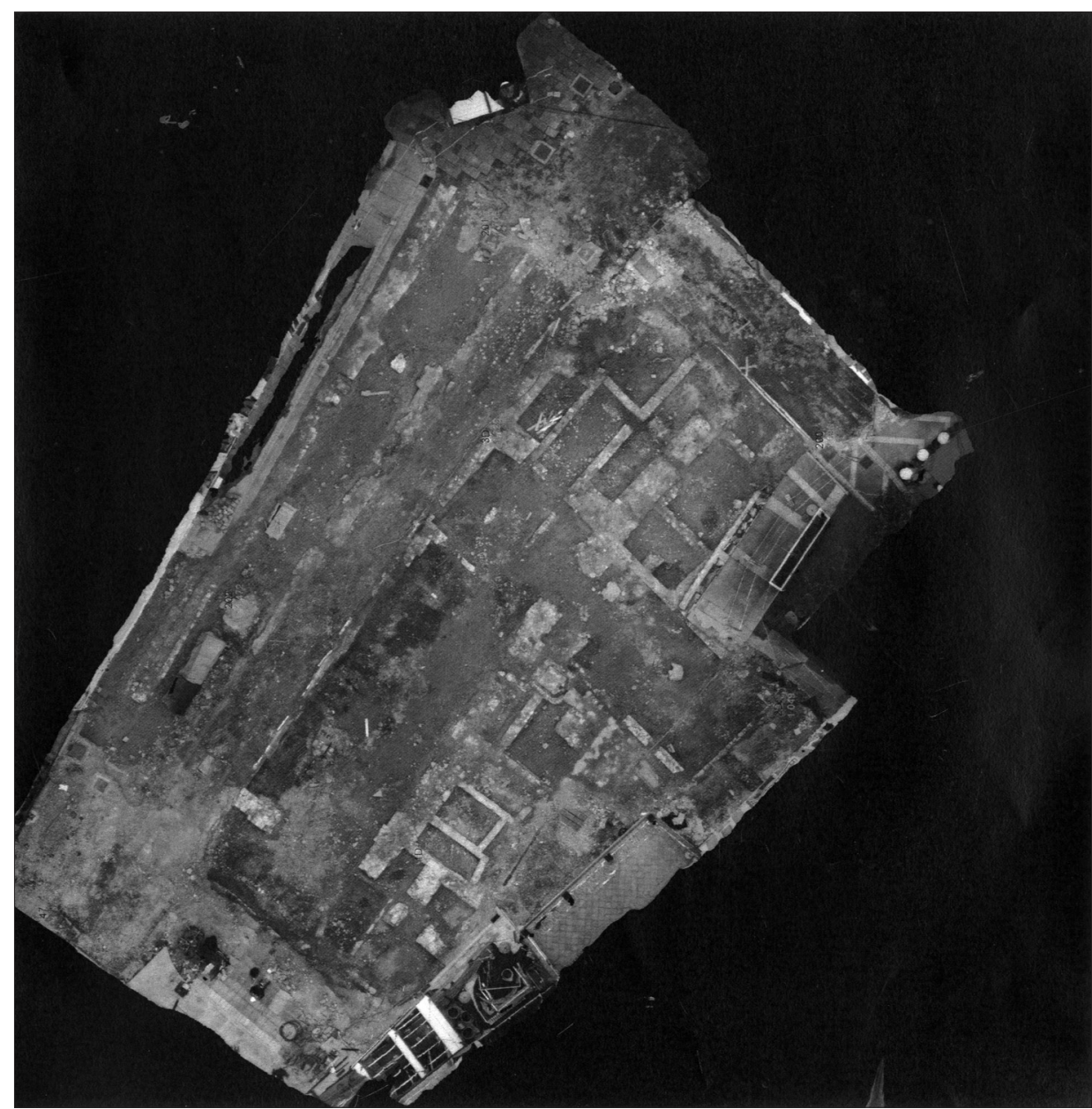

S1. 3. Fotogrametrijski prikaz Pavlinskog trga (izradio: V. Madiraca) $)^{10}$

Ovakvu je situaciju moguće naslutiti na temelju Valvasorove vedute iz 1689. i plana Senja iz 1763. godine.

Uz južno lice pretpostavljenog trijema proteže se nadsvođeni kanal pretpostavljene širine oko $2 \mathrm{~m}$. Riječ je o kanalu kojim je bila regulirana bujicapotok do uređenja regulacije krajem 18. st. kada je potok preusmjeren uz vanjsko

${ }^{10}$ Arheološku nacrtnu dokumentaciju i fotogrametrijski prikaz Pavlinskog trga izradio je Vinko Madiraca, dipl. arheolog, (Konzervatorski odjel u Gospiću), koji je vršio konzervatorski nadzor nad radovima. Koristim priliku i zahvaliti mu na svekolikoj i svesrdnoj stručnoj pomoći tijekom provođenja arheološkog nadzora na lokalitetu Pavlinski trg u Senju. 


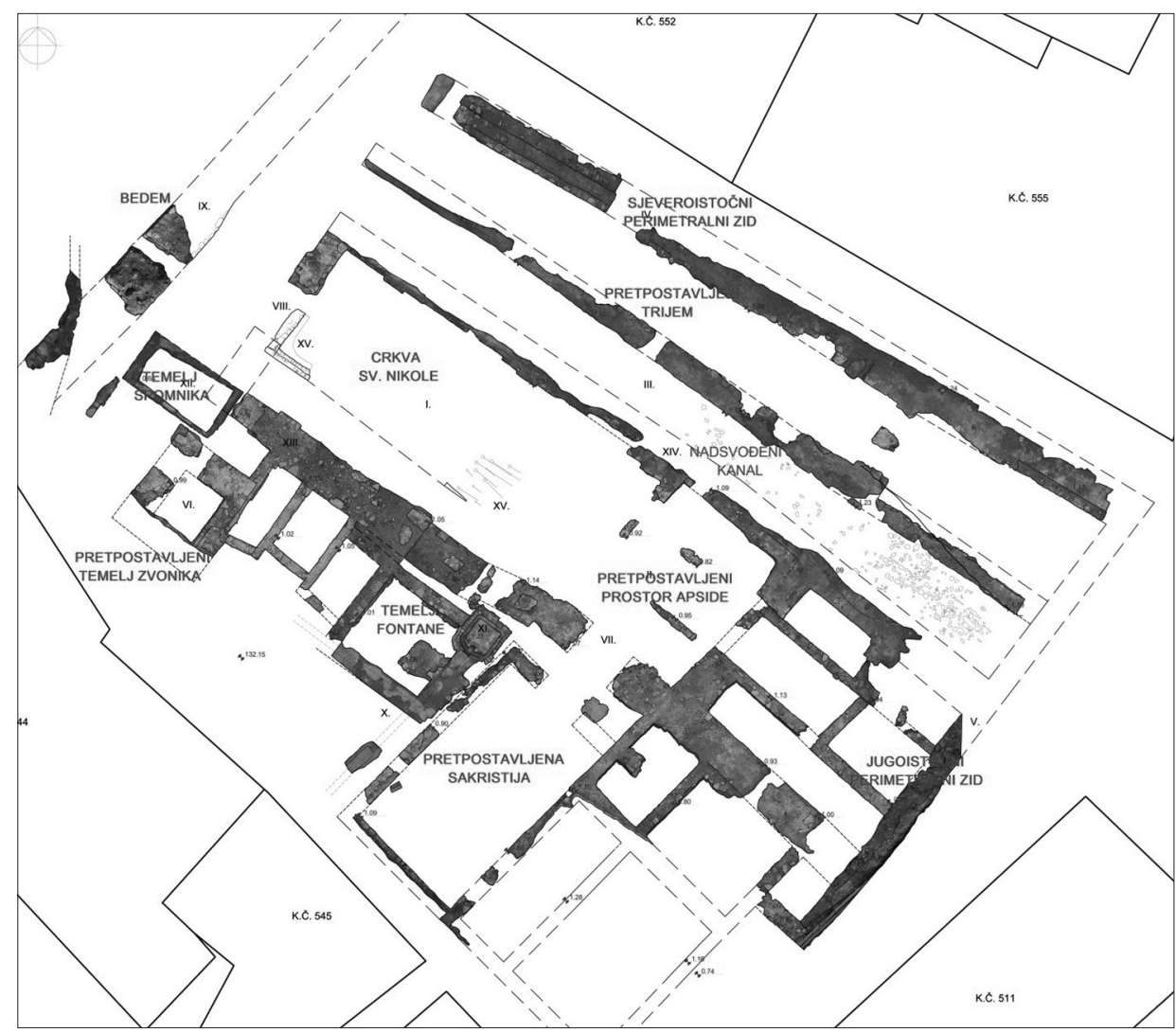

S1. 4. Snimka Pavlinskog trga s ucrtanim otkopanim zidovima - gabaritima crkve sv. Nikole sa samostanom i dijelom bedema (izradio: V. Madiraca)

lice južnih gradskih zidina. Do ove faze potok je tekao kroz areal grada unutar zidina, tj. južni dio grada te kroz sjeveroistočni dio pavlinskog samostana. Potok je jasno vidljiv na već spomenutom planu iz 1763. godine na kojem se vidi blaži otklon korita potoka u smjeru zapada. Navedeni otklon vidljiv je i u pružanju ostataka kanala na današnjem Pavlinskom trgu.

Spomenuti otklon toka potoka vjerojatno je utjecao i na otklon temeljnih vanjskih zidova broda/brodova crkve sv. Nikole. Crkva sv. Nikole prostire se dalje u smjeru juga, a linijom pružanja prati smjer korita potoka te sjeveroistočnog perimetralnog zida. Temeljni vanjski zidovi debljine su između 1,20 (zapadno pročelje) i 1,80 m (vanjski jugozapadni zid). Na unutarnjim licima vanjskog sjeveroistočnog i jugozapadnog zida razaznaju se ostaci pilona, vidljivi i na 


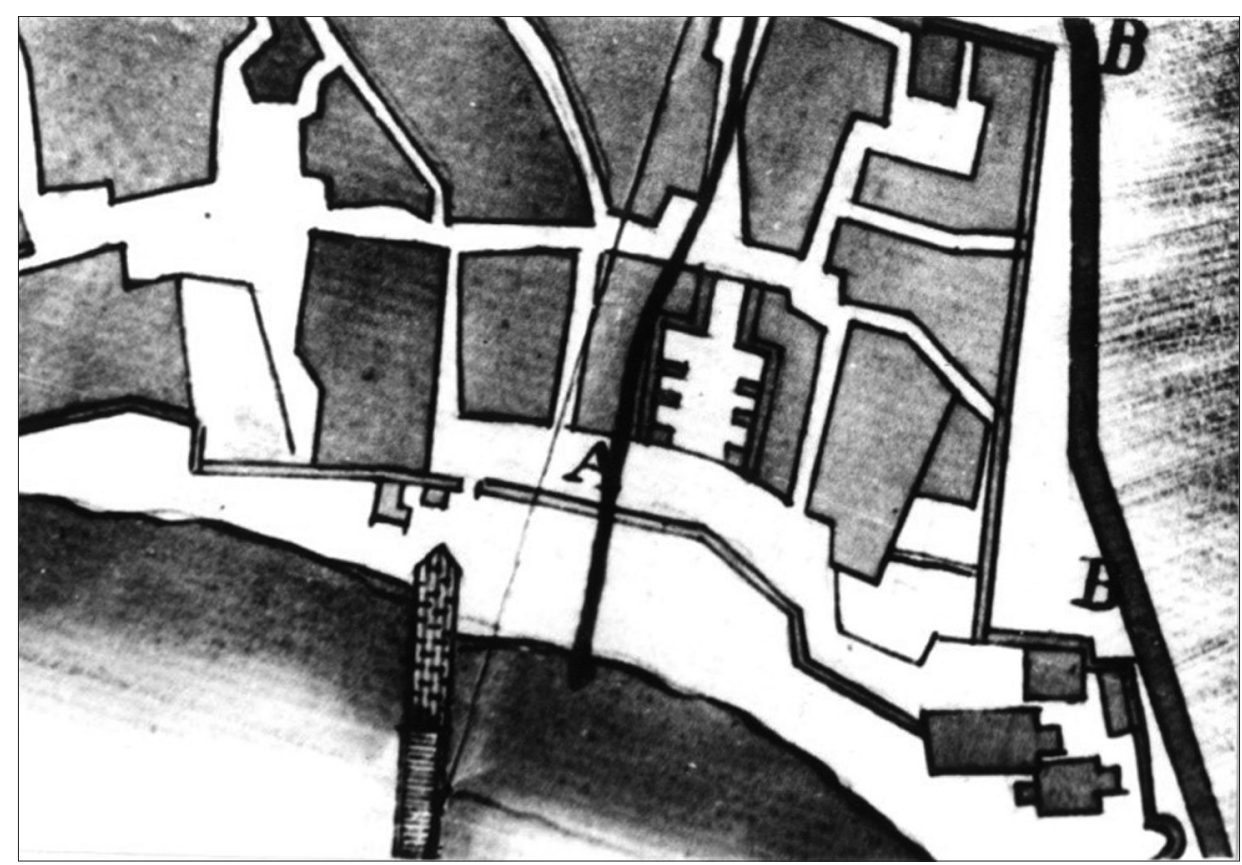

S1. 5. Isječak plana Senja iz 1763. godine s prikazom samostana (izvor: Beč, Arhiv dvorske komore: O-162 ${ }^{11}$ )

planu iz 1763. te sjeverni temeljni zid zapadnog pročelja u nastavku kojeg se nalazio glavni ulazni portal. Južni temeljni zid zapadnog pročelja u potpunosti nedostaje jer ga je devastirao betonski temelj spomenika Tri mornara. U istočnom dijelu temelja jugoistočnog vanjskog zida vidljiv je proboj za vrata kojima se pristupalo iz prostora crkve prema većoj prostoriji pravokutnog tlocrta, moguće sakristiji, dimenzija 9,70 x 5,60 m i površine unutarnjeg prostora od oko $42 \mathrm{~m}^{2}$. U istočnom dijelu crkve vidljivi su sporadično ostaci tanjih zidova koji bi mogli pripadati prostoru apside. Međutim, isti su previše oskudni da bi omogućili preciznije rekonstruiranje izgleda svetišta koje se nedvojbeno nalazilo na ovom prostoru (plan iz 1763.). Crkva sv. Nikole pretpostavljene je duljine s apsidom oko $22 \mathrm{~m}$, a širine oko $9,80 \mathrm{~m}$.

U prostoru između crkve i jugoistočnog perimetralnog zida vidljiv je splet zidova širine između 0,40 i 1,50 m koji čini sklop od 9 pretpostavljenih prostorija nepoznate namjene, a koje pripadaju sklopu samostana. Sklop

${ }^{11}$ M. VILIČIĆ, 1971. 


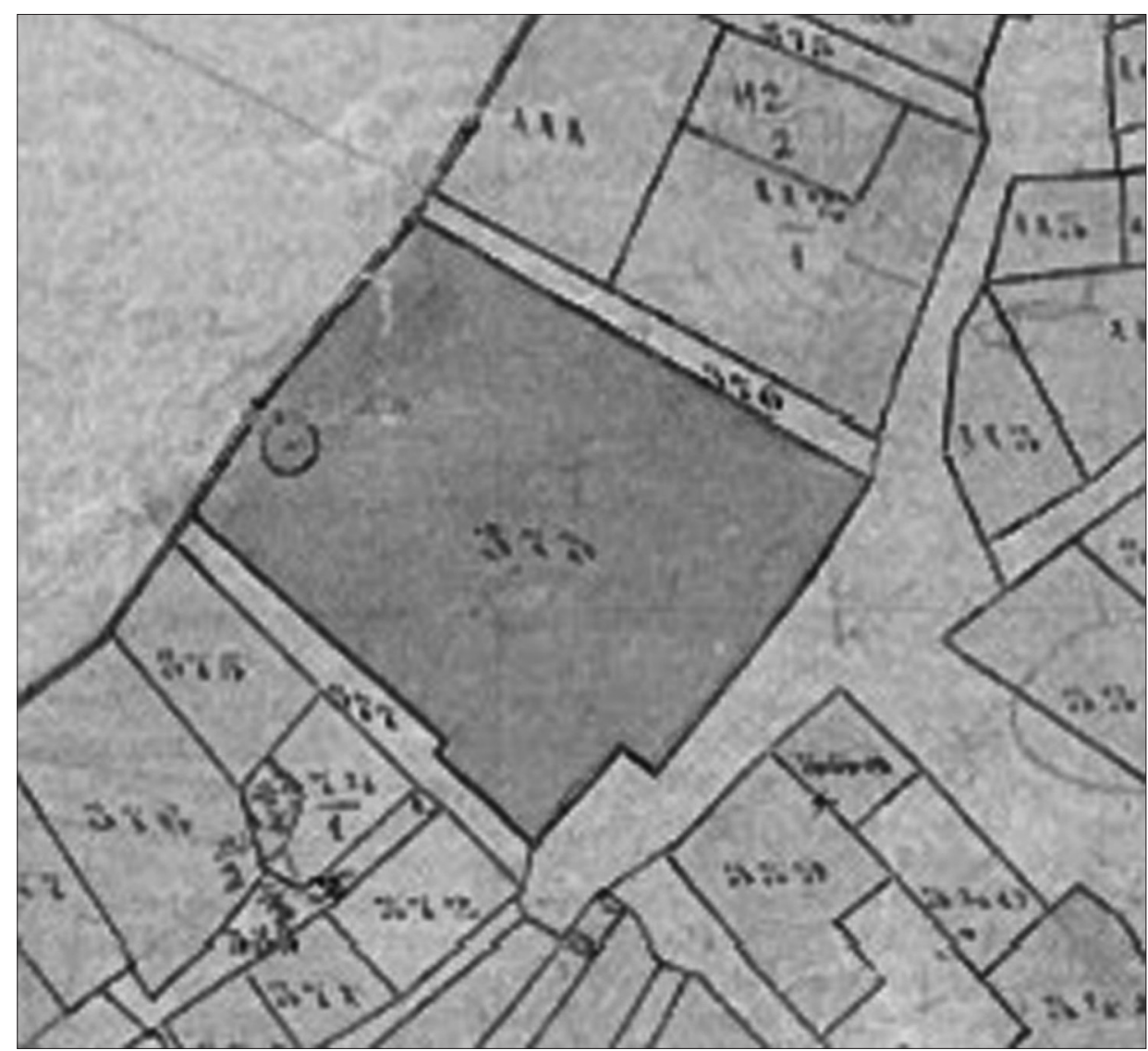

S1. 6. Isječak katastarskog plana s vidljivim konturama samostana (izvor: Odjel za katastar nekretnina Senj)

je prema sjeverozapadu vezan uz pretpostavljenu sakristiju te je $\mathrm{s}$ istom formirao južno izbočeno krilo samostana (vidljivo na katastarskom planu iz 19. st.).

U uglovima koji čine temelj jugozapadnog zida crkve i temelj sjeverozapadnog zida sakristije vidljivi su temeljni ostaci fontane postavljene na trgu nakon rušenja samostana 1874. na koje se u smjeru jugozapada $i$ sjeverozapada vežu odvodni kanali. Isti su kanali vjerojatno devastirali dio prostorija samostanskog sklopa nanizanih uz jugozapadni zid crkve prema obali. U istom su smjeru vidljivi temelji tri manje prostorije sklopa nepoznate namjene. 


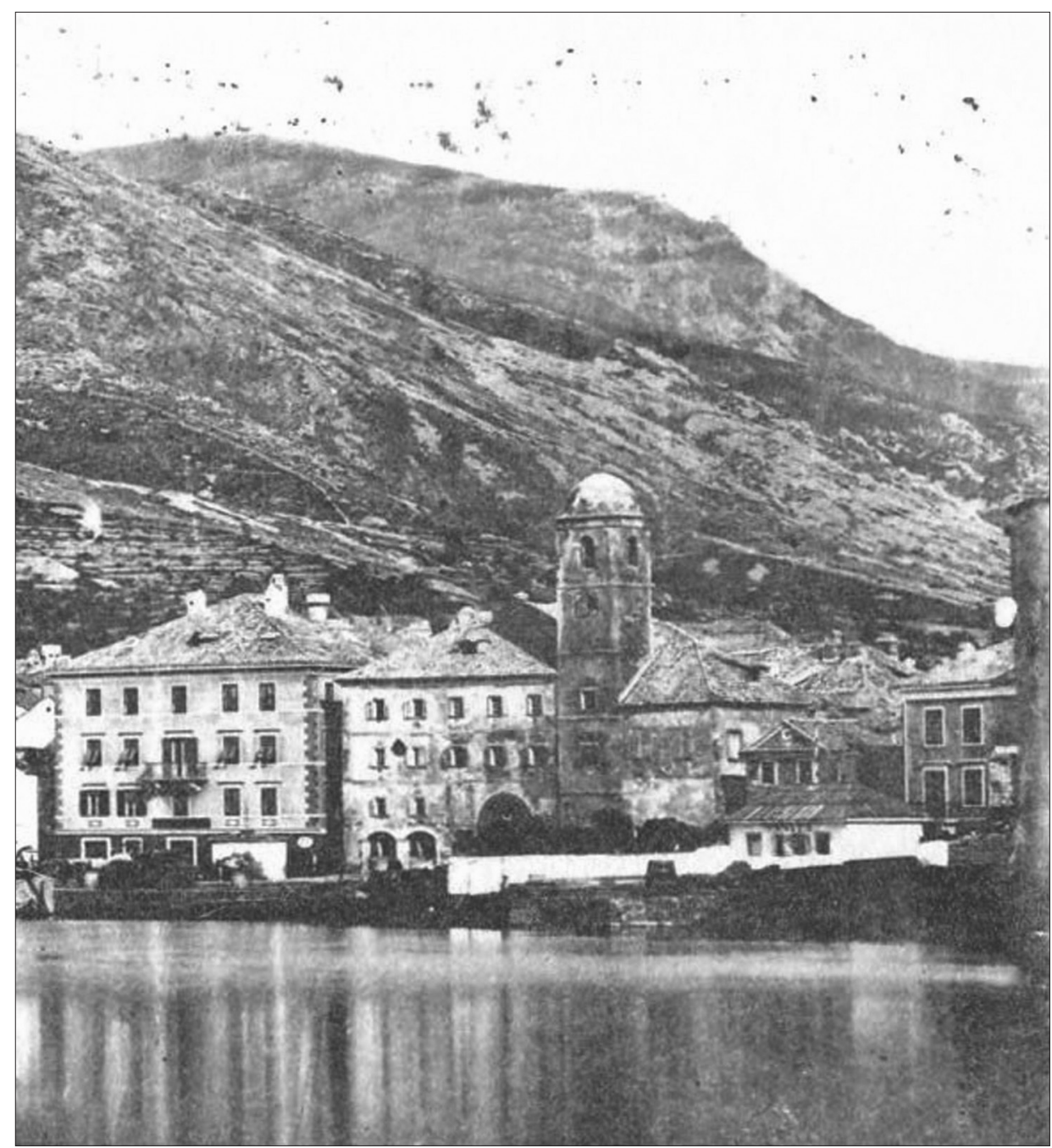

Sl. 7. Fotografija samostanskog sklopa iz 1869. godine (izvor: HKS, 1940, slika 24)

$\mathrm{Na}$ samom sjeverozapadnom završetku sklopa u liniji sa zapadnim pročeljem crkve utvrđeni su djelomično očuvani temeljni zidovi debljine do $1,20 \mathrm{~m}$ prostorije pretpostavljenog kvadratnog tlocrta. Pozicijom, tlocrtom i orijentacijom konstrukcija sugerira se da je riječ o temelju zvonika crkve vidljivog na Standlovoj fotografiji iz 1869. i prikazu Senja iz 1814. godine. 


\section{Zaključak}

Na dubini od 0,50 m na području Pavlinskog trga u Senju otkriveni su arhitektonski ostaci crkveno-samostanskog kompleksa, kao i ostaci obrambenog bedema prema moru, koji je izgrađen od klesanih kamenih blokova vezanih vapnenim mortom.

Arheološkim nadzorom na Pavlinskom trgu utvrđeno je da je ranijim građevinsko-komunalnim radovima došlo do devastacije arheološkog lokaliteta i grobova u perimetru crkve, što dokazuju ispremještani ostaci građevinskog materijala $\mathrm{i}$ šute $\mathrm{s}$ ljudskim kostima i ulomcima keramike. Također su utvrđene velike količine recentne građevinske šute i smeća pomiješanog s krovnom opekom, komadima kamena (ostaci rušenja), kojim je uglavnom bio prekriven dio platoa crkve. Želimo napomenuti da su raniji radovi bili svakako provedeni u dobroj namjeri onih koji su ih izvodili s ciljem uređenja Trga, ali nažalost nepoznavanjem povijesti i važnosti ovoga prostora, na kojem se do 1874. godine nalazio pavlinski samostan i crkva sv. Nikole, dogodila se neželjena devastacija lokaliteta, što su potvrdila posljednja istraživanja.

Pokretni arheološki nalazi pohranjeni su u Gradskom muzeju Senj. Otvorenim ostaje mogućnost eventualne prezentacije ovoga zanimljivog i važnog crkveno-samostanskog kompleksa za crkvenu povijest grada Senja.

\section{Literatura}

Mile BOGOVIĆ, Pavlini u Senju, Senjski zbornik, 15, Senj, 1988, 109-120.

Vedrana GLAVAŠ - Miroslav GLAVIČCIĆ, Izvješće o probnom arheološkom istraživanju lokaliteta Senj - Pavlinski trg 2012., Senjski zbornik, 39, Senj, 2012, 35-74.

Ante GLAVIČIĆ, Stara i nova groblja, grobovi na području grada Senja i šire senjske okolice (I), Senjski zbornik, 19, Senj, 1992, 81-108.

Zorislav HORVAT, Srednjovjekovna pavlinska arhitektura na području Senjskomodruško-krbavske biskupije, Senjski zbornik, 26, Senj, 1999, 163-167.

Hrvatski kulturni spomenici, JAZU, I, Senj, Zagreb, 1940.

Ivan KUKULJEVIĆ-SAKCINSKI, Nadpisi sredovječni i novovjeki na crkvah i javnih $i$ privatnih sgradah u Hrvatskoj i Slavoniji, Zagreb, 1891.

Mile MAGDIĆ, Topografija i povijest grada Senja, Senj, 1877.

Pavao TIJAN, Vodič po Senju i okolici, Senj, 1931.

Melita VILIČIĆ, Arhitektonski spomenici Senja, Rad JAZU, Knjiga 360, Zagreb, 1971.

Melita VILIČIĆ, Skice grafičkih rekonstrukcija nekih drevnih senjskih sakralnih građevina, Senjski zbornik, 18, Senj, 1991, 277-300. 


\section{REPORT ABOUT THE ARCHAELOGICAL SUPERVISION \\ ON THE SITE OF PAVLINSKI TRG IN SENJ \\ (NOVEMBER 2019 - JUNE 2020)}

\section{Summary}

The archaeological supervision of the construction works on Pavlinski trg (Pauline Square) in Senj was carried out by Senj Town Museum. The specialist leader of the supervision concerned was Blaženka Ljubović, MSc. Education (History) and MSc. Archaeology, along with the conservation supervision of Vinko Madiraca, BSc. an archaeologist from the Conservation Department in Gospić. The mentioned construction works were carried out in the period from November 2019 to the end of June 2020.

In the past, according to historical sources, Pavlinski trg in Senj was the location of a Dominican and then Pauline monastery with the Church of St Nicholas, which due to its state of disrepair was demolished in 1874 with part of the city wall in the area of the old sea gate. The subject of this paper is the archaeological supervision of the protection of the Pavlinski trg site (the area of the former Pauline Church of St Nicholas and the monastery in Senj) during the construction works of the landscaping of the square. Supervision was carried out in order to collect all the relevant information about the cultural strata and archaeological finds, especially because during earlier archaeological research archaeological material (grave finds) was documented from certain historical periods of the church-monastery complex, as well as immovable architectural structure, archaeologically interesting, at certain depths from the level of the pavement of Pavlinski trg. The aim of the archaeological supervision was to determine the dimensions of the church and monastery and to protect any possible graves inside the church from possible destruction.

Keywords: Senj, Pavlinski trg, church and monastery of St Nicholas, archaeological supervision, the Middle Ages, the New Age, graves, walls, human bones, ceramics, money 
ARHEOLOŠKI NALAZI NA LOKALITETU NEKADAŠNJEG SAMOSTANA I CRKVE SV. NIKOLE U SENJU ${ }^{12}$

T. I. Ulomci keramike (Sl. 1. - Sl. 5.)

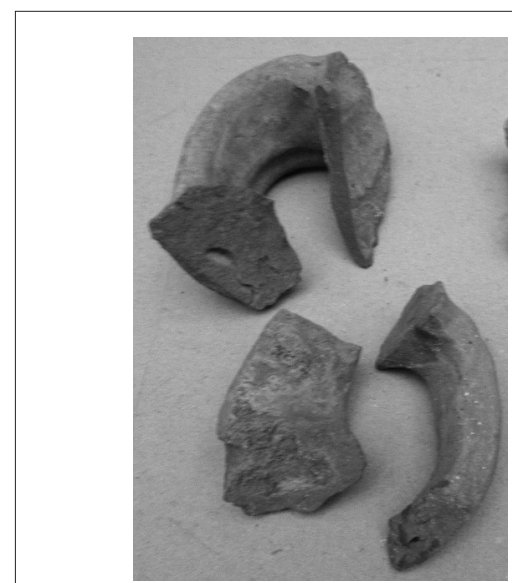

S1. 1.

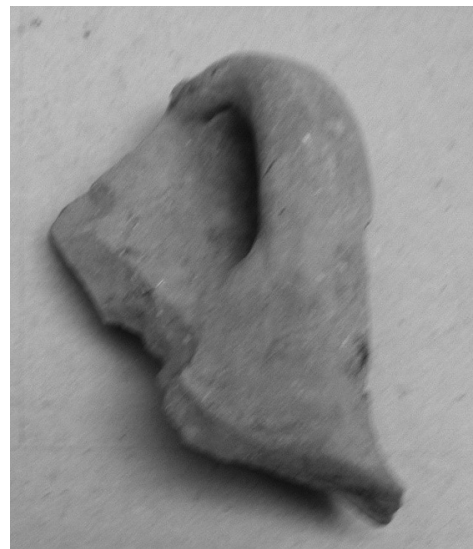

S1. 2.

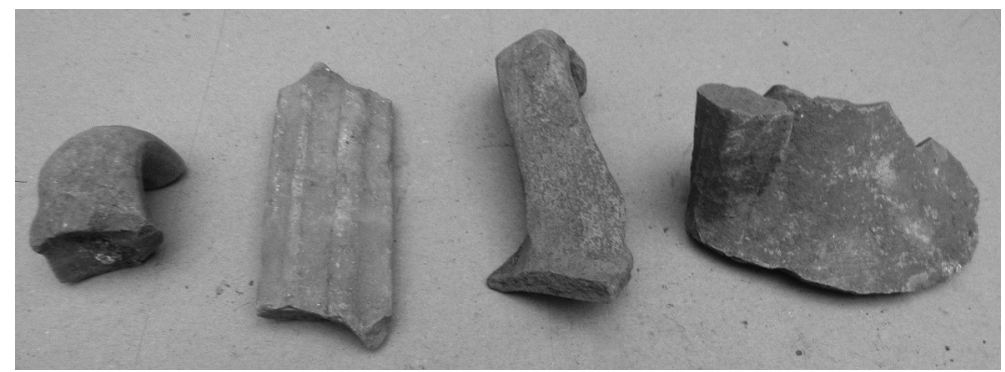

Sl. 3.

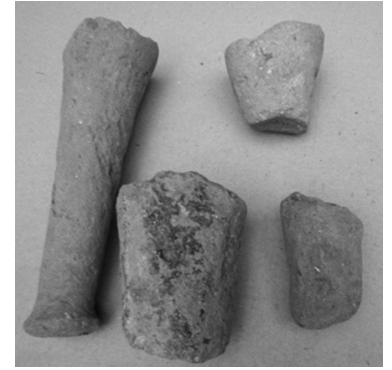

S1. 4.

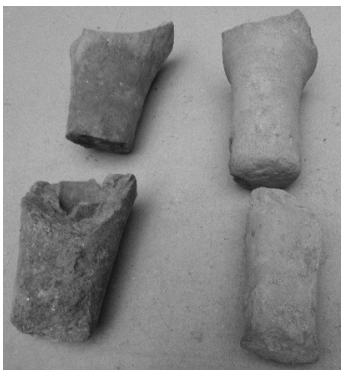

S1. 5 .

${ }^{12}$ Foto: Blaženka Ljubović, 2020. 
T. II. Nađeni novac (Sl. 6. a), 6. b) i 7.)
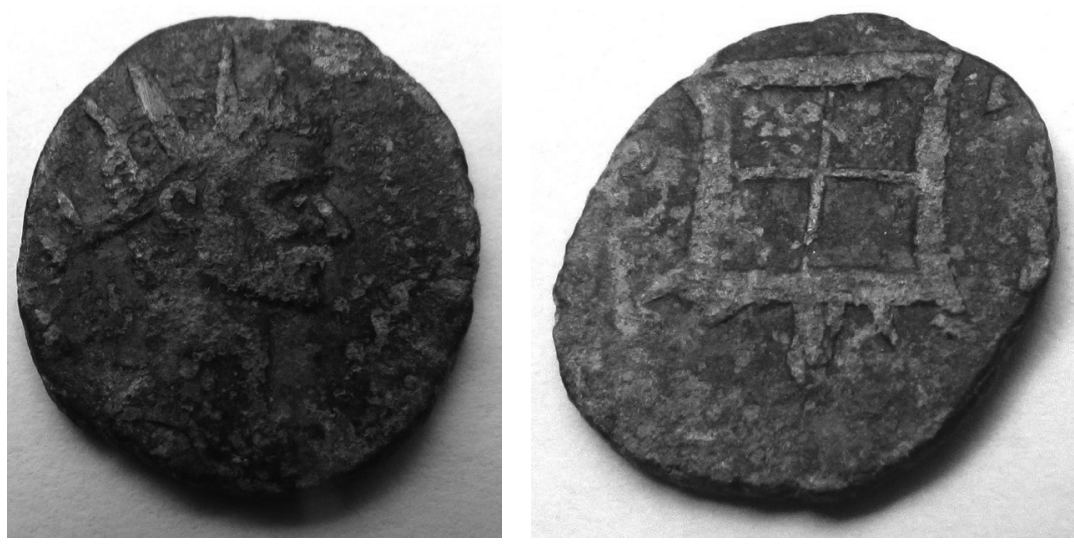

Sl. 6. a) i 6. b) - Antički novac po tipu Antoninijan iz vremena Klaudija II. Gotskog (268. - 270.); avers: glava s radijalnom krunom, desno; revers: CONSECRATIO, pravokutni monolitni žrtvenik

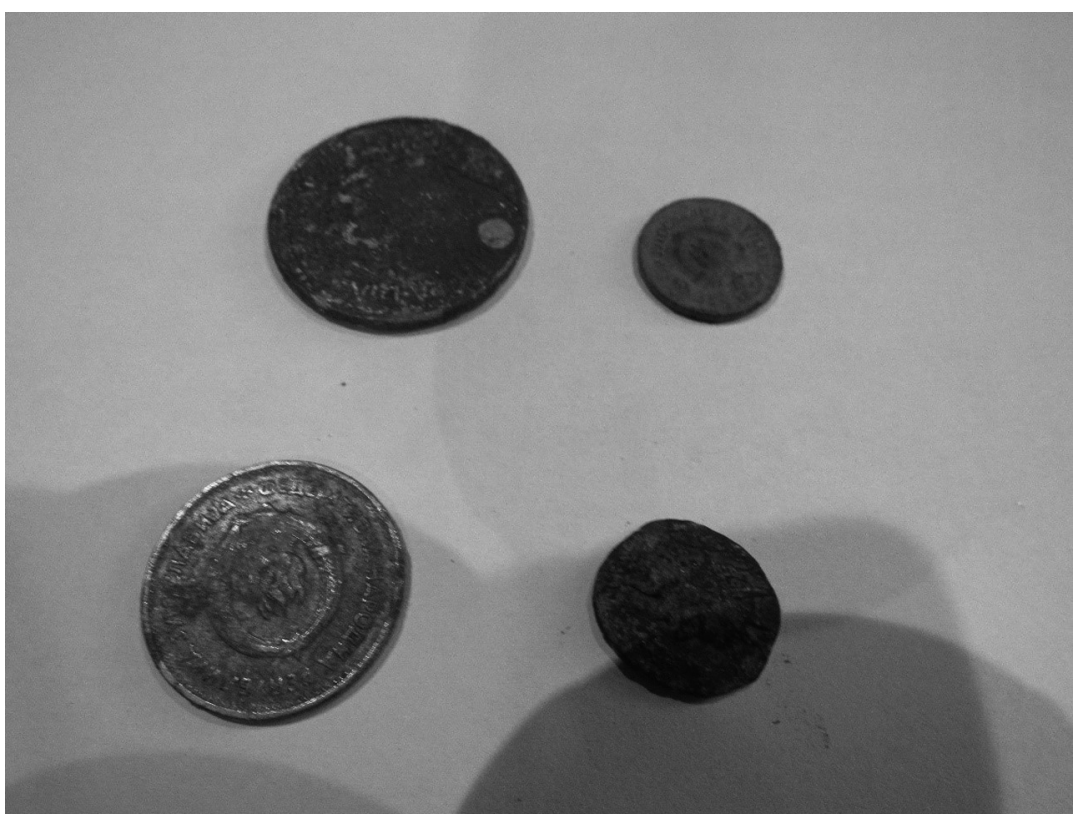

Sl. 7. Kovanice jugoslavenskih dinara 
T. III. Ulomak stupa (Sl. 8. a) i 8. b))

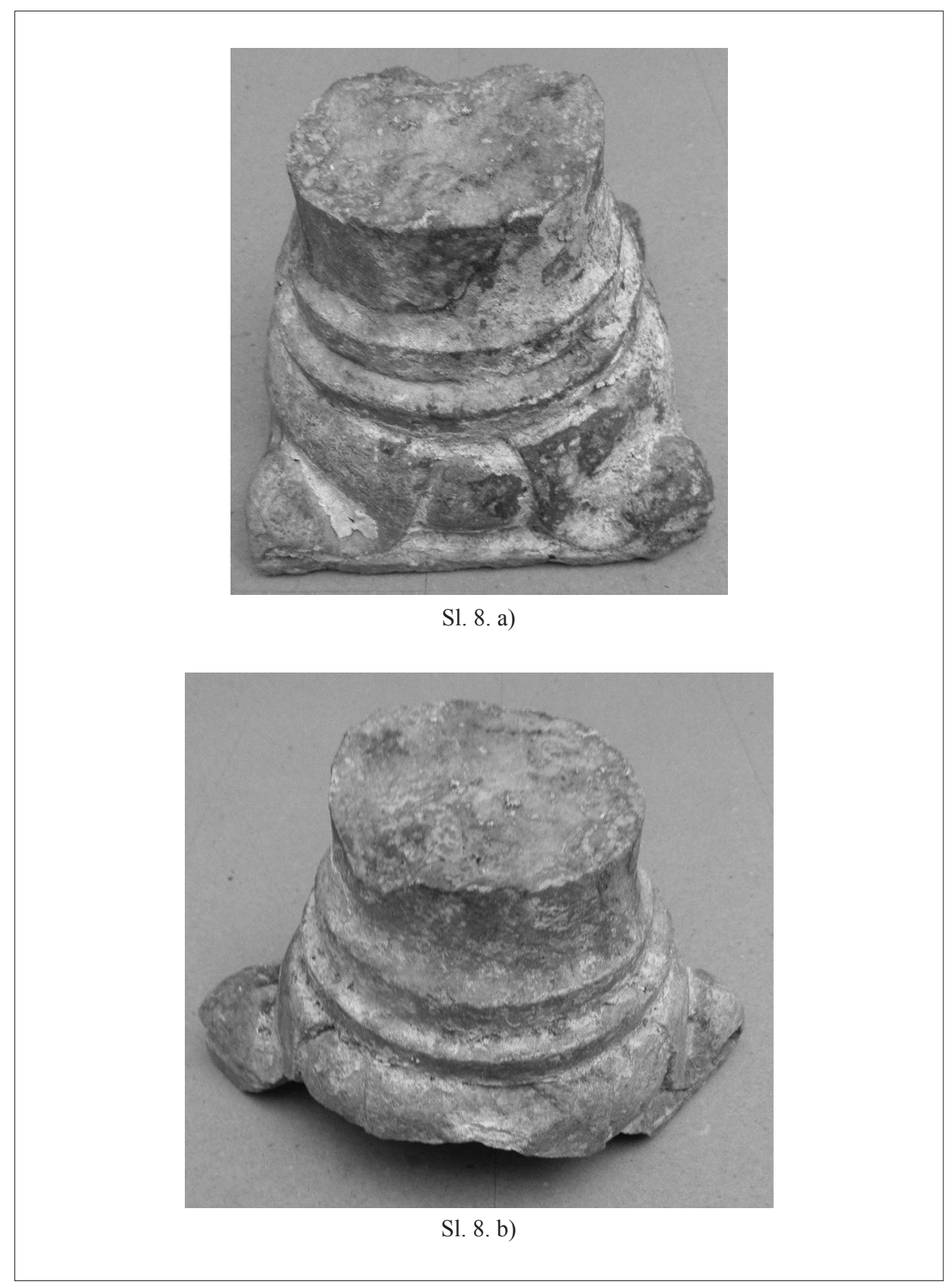


FOTOGRAFIJE PAVLINSKOG TRGA PRIJE, TIJEKOM I NAKON ARHEOLOŠKIH ISTRAŽIVANJA

\section{T. IV. - Pavlinski Trg nekada}

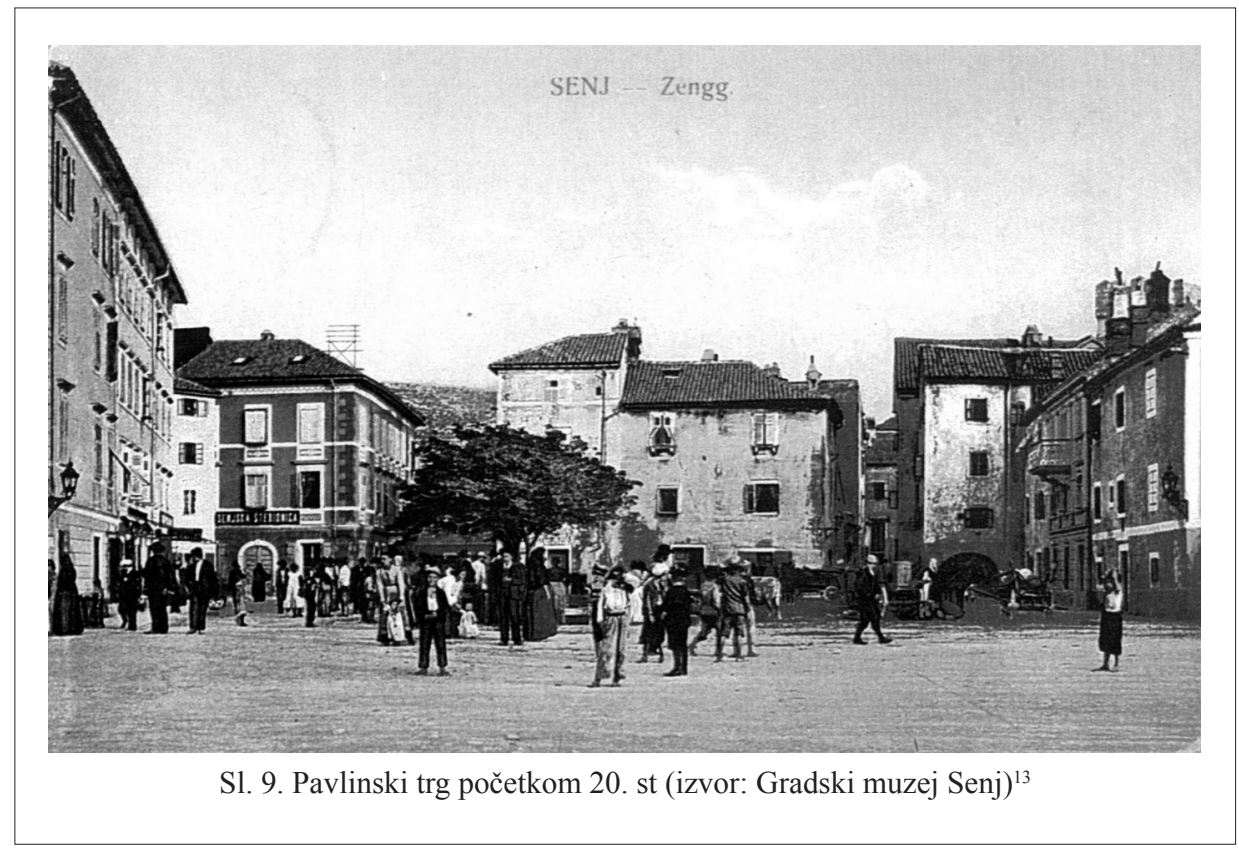

${ }_{13}$ Razglednica se nalazi u Zbirci fotografija, razglednica i dopisnica Gradskog muzeja Senj. Nakladnik razglednice je Quarn. Ed. Feitzinger's Kunstverlag, a mjesto tiskanja je Teschen. Izrađena je u boji, a poslana je poštom iz Rijeke u Garešnicu. 
T. V. - Pavlinski trg tijekom arheoloških istraživanja (Sl. 10. - Sl. 15. $\left.{ }^{14}\right)$

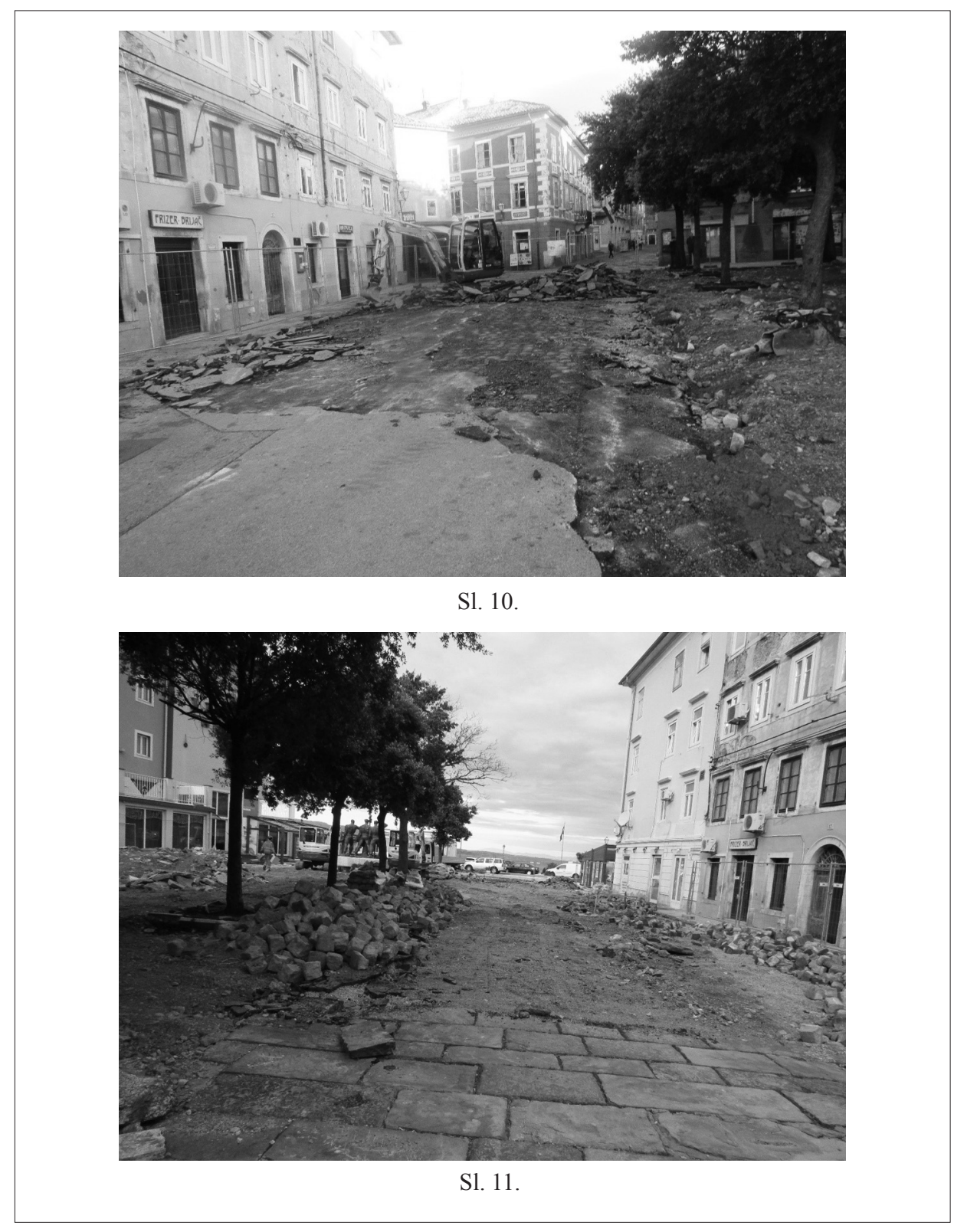

${ }^{14}$ Foto: Blaženka Ljubović, 2019. i 2020. 


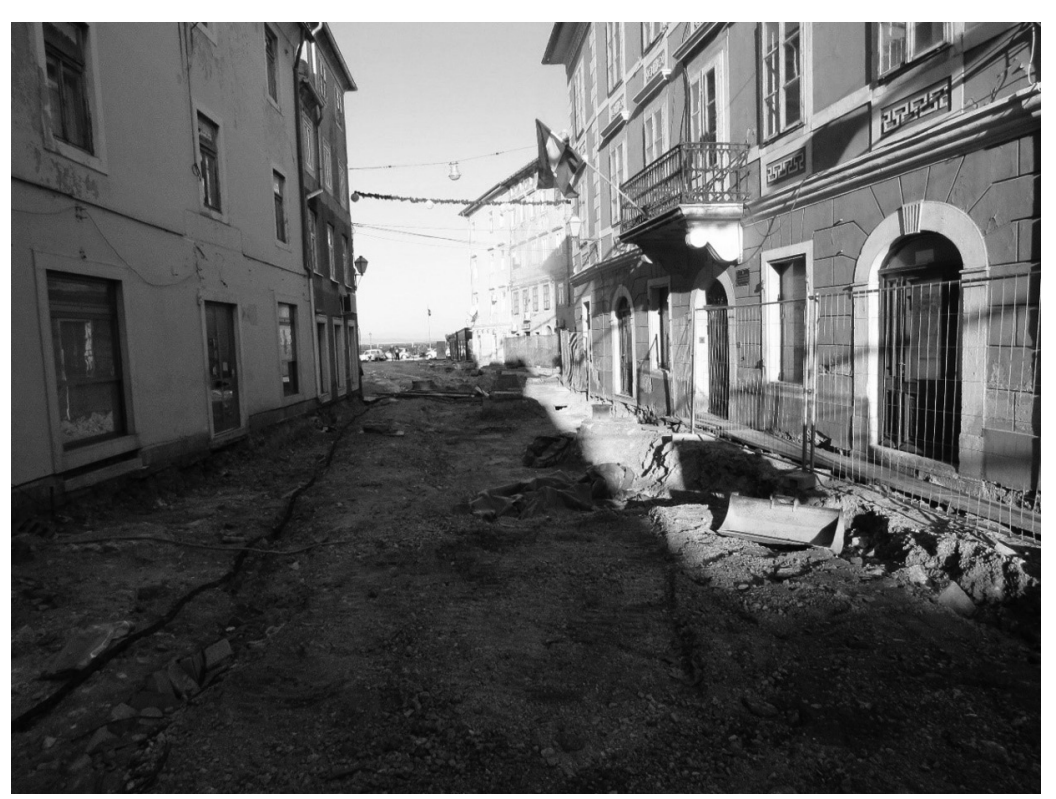

S1. 12.

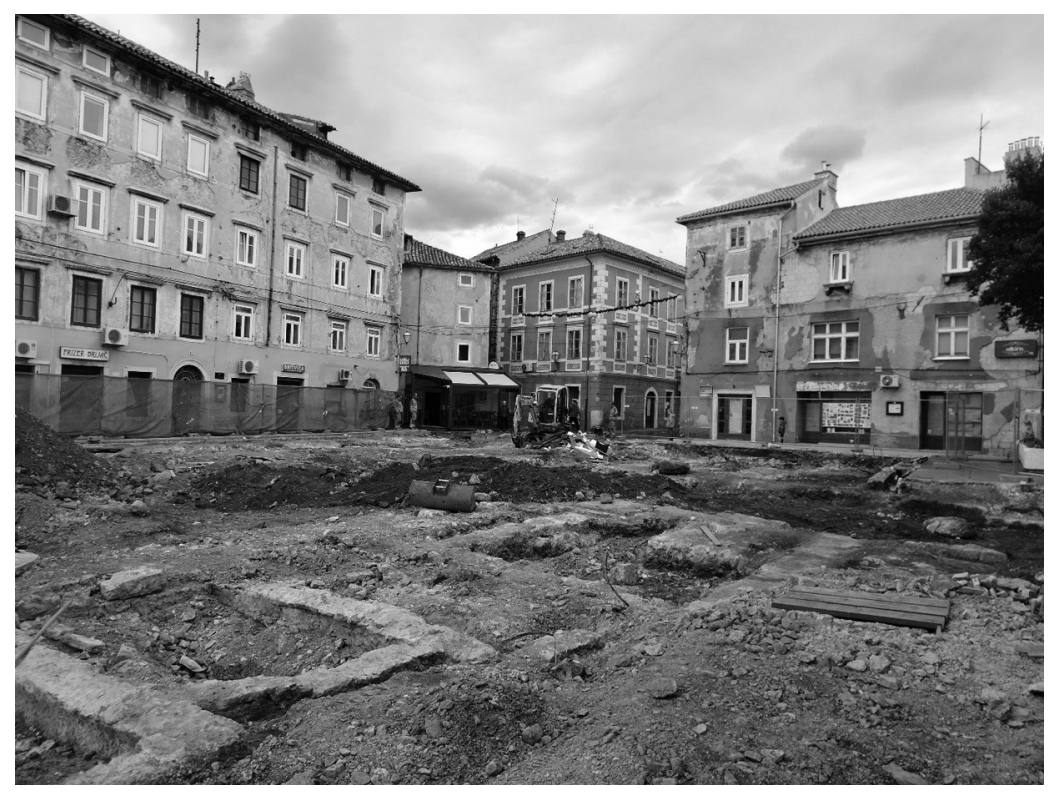

S1. 13. 


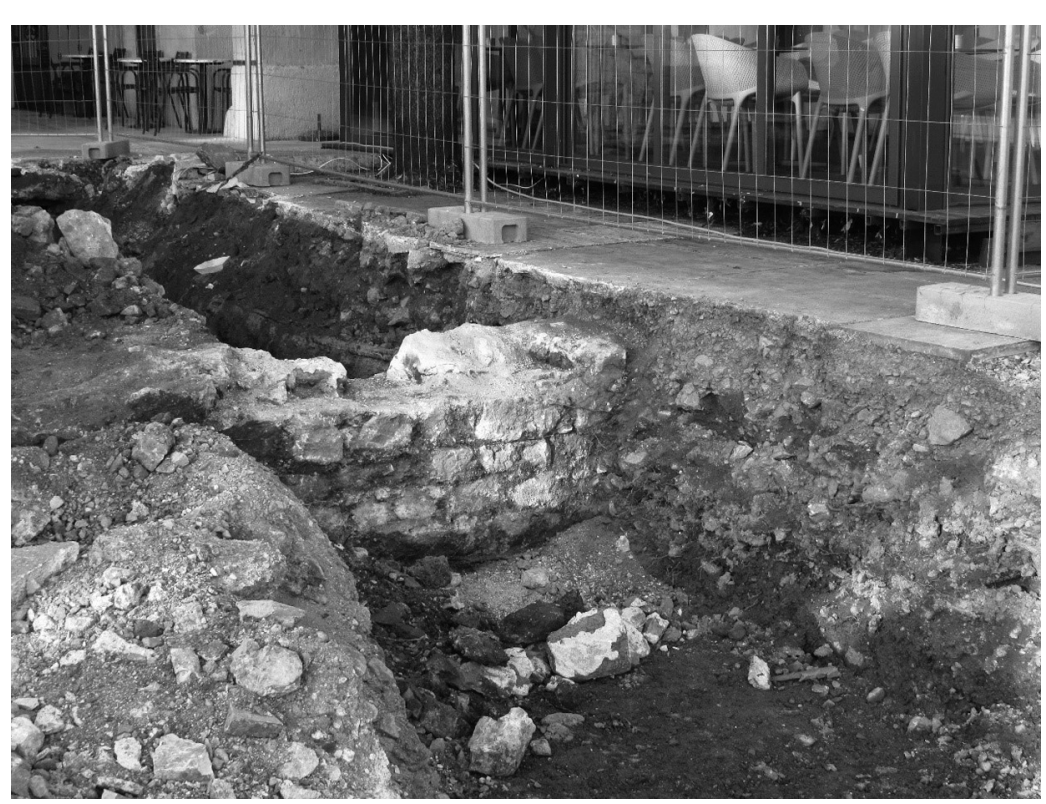

S1. 14.

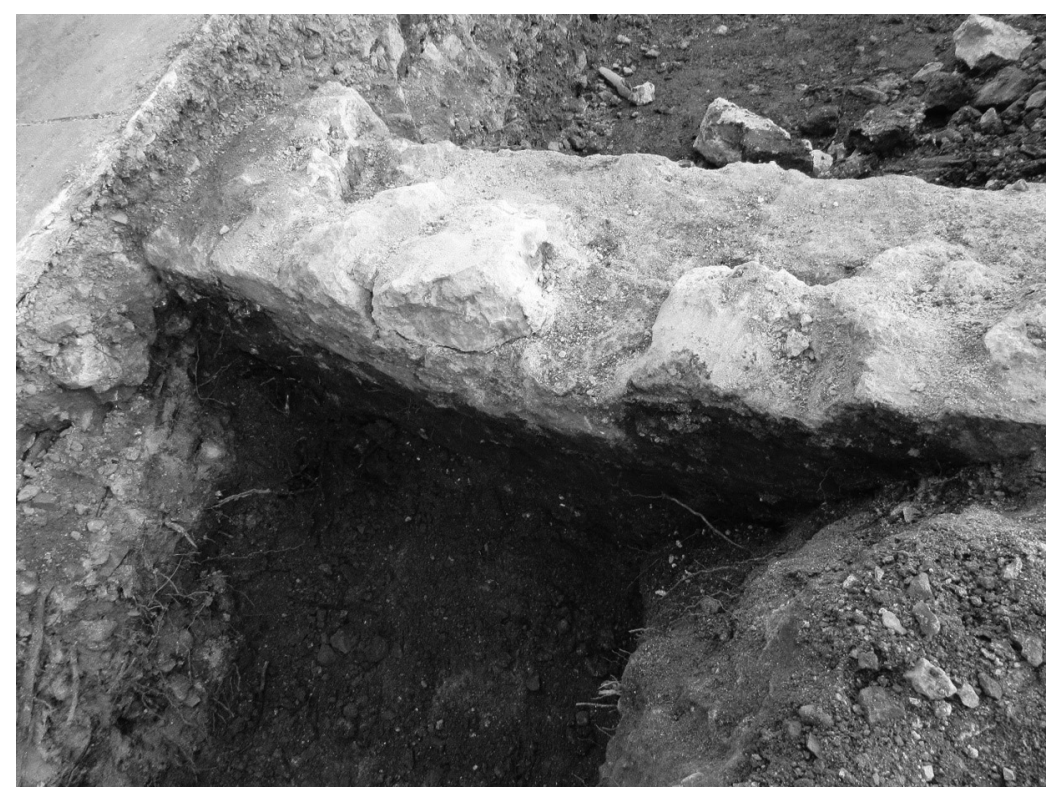

S1. 15. 
T. VI - Pavlinski trg nakon arheoloških istraživanja (Sl. 16. i 17.) ) $^{15}$

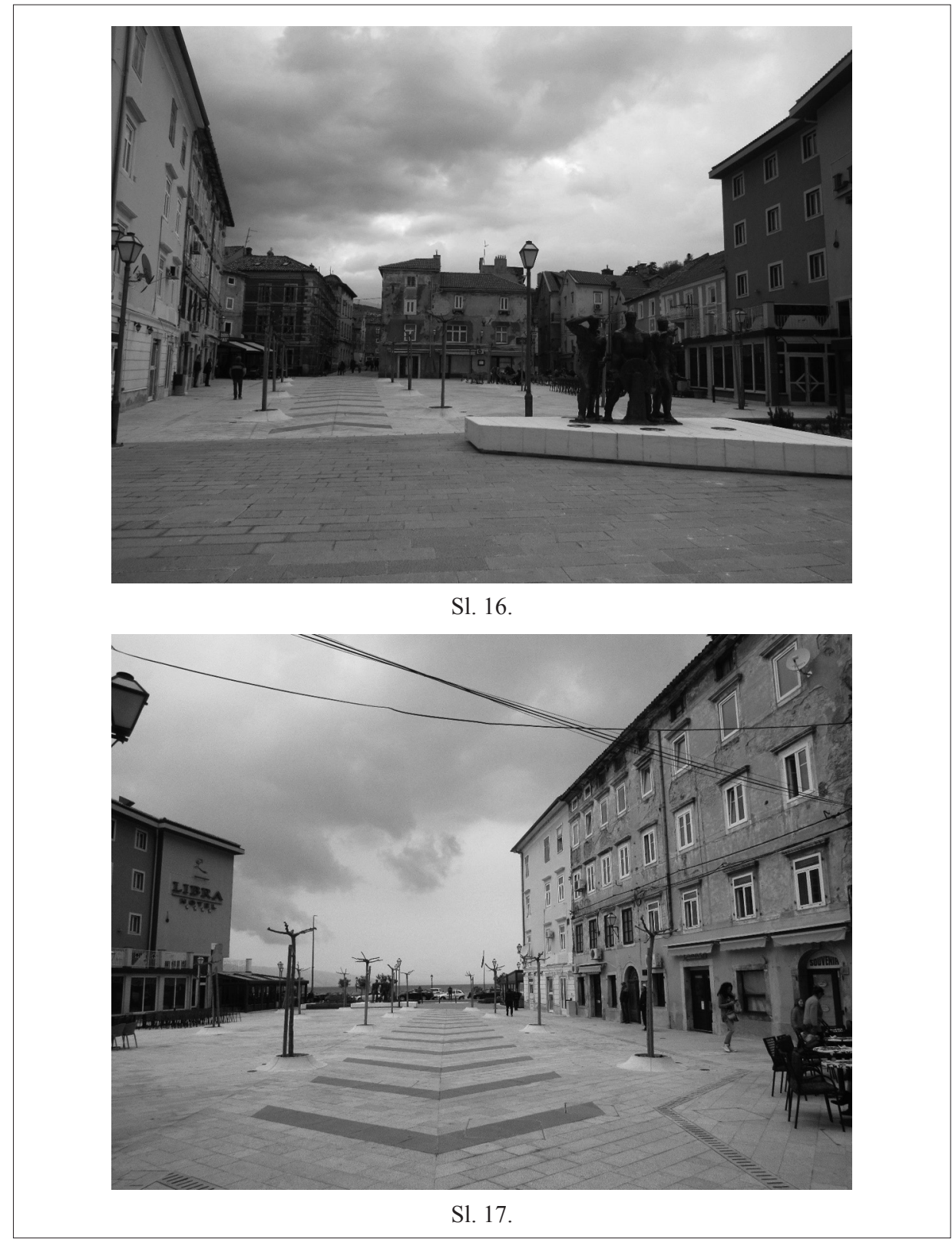

${ }^{15}$ Foto: Blaženka Ljubović, 2020. 